\title{
Pensonomonoor
}

2016, vol. 75, 131-139

http://dx.doi.org/10.12657/denbio.075.013

\author{
Larisa Orlova, Gennady Firsov, Alexandr Egorov, \\ Alexandra Volchanskaya
}

\section{Abies semenovii in North West Russia: taxonomy, ecology, cultivation and conservation}

\author{
Received: 6 June 2015; Accepted: 18 February 2016
}

\begin{abstract}
Semenov's Fir (Abies semenovii B. Fedtsch.) is an extremely rare species in the wild and is included in the International Red List of Conifers and into the Red Data Books of the former USSR and Kyrgyz Republic. Our investigation confirms that this is an independent species, related but not identical to Abies sibirica Ledeb. It has been cultivated at Peter the Great Botanic Garden of the Komarov Botanical Institute of the Russian Academy of Science(s), St.Petersburg, since 1949. Apparently, it was here that Semenov's Fir was first introduced into cultivation in European gardens. It has produced seeds since 2000, when it was less than 43 years old. It is a hardy and ornamental tree that deserves wider distribution in cultivation in the gardens and parks of North-West Russia. It is proposed that Semenov's Fir should be given independent taxonomic status as a separate species, Abies semenovii B. Fedtsch.
\end{abstract}

Key words: morphology, taxonomy, arboriculture, botanic gardens, Red Data Book, Saint-Petersburg.

Addresses: L.V. Orlova, Herbarium Higher Plants, Komarov Botanical Institute, Russian Academy of Sciences, Prof. Popov street, 2, 197376, St. Petersburg, Russia, e-mail: orlarix@mail.ru

G.A. Firsov, A.V. Volchanskaya, Peter the Great Botanic garden, Komarov Botanical Institute, Russian Academy Science, Prof. Popova street, 2, 197376, St. Petersburg, Russia.

A.A. Egorov, Department of Biogeography and Conservation, St. Petersburg State University, Universitetskaya nab., 7-9, 199034, St. Petersburg, Russia; Department of Botany and Dendrology, St. Petersburg State Forest Technical University, Instituskyi per., 5, 194021, St. Petersburg, Russia

\section{Introduction}

Semenov's Fir (Abies semenovii B. Fedtsch.) is a rare endemic species of Central Asia (Farjon \& Page, 1999; Bikirov, 2009, 2011; Orlova \& Firsov, 2015). In the wild this species occurs in Kyrgyzstan, in the mountains of Central Tien Shan (Fig. 1) where its natural habitat is limited to the Talas Tau, Chatkal, and Susamir mountains ridges of the Tien-Shan Mountains (Farjon, 2001). It grows on the shady slopes of mountain river valleys at $1200-2800 \mathrm{~m}$ above sea level. At the lower limits of its distribution the species grows together with Juglans regia L. and other broad-leaved species. It forms mixed forests with Picea schrenkiana Fisch. et C.F. Mey. In the area around Sarah Chelek Lake Semenov's Fir forms spruce-fir forests dominated by Picea schrenkiana but including Sorbus tianschanica Rupr., Lonicera hispida Pall., L. stenantha Pojark., Ribes meyeri Maxim., Rubus idaeus L. and Atragene sibirica L. (Kamelin, 1973). The 

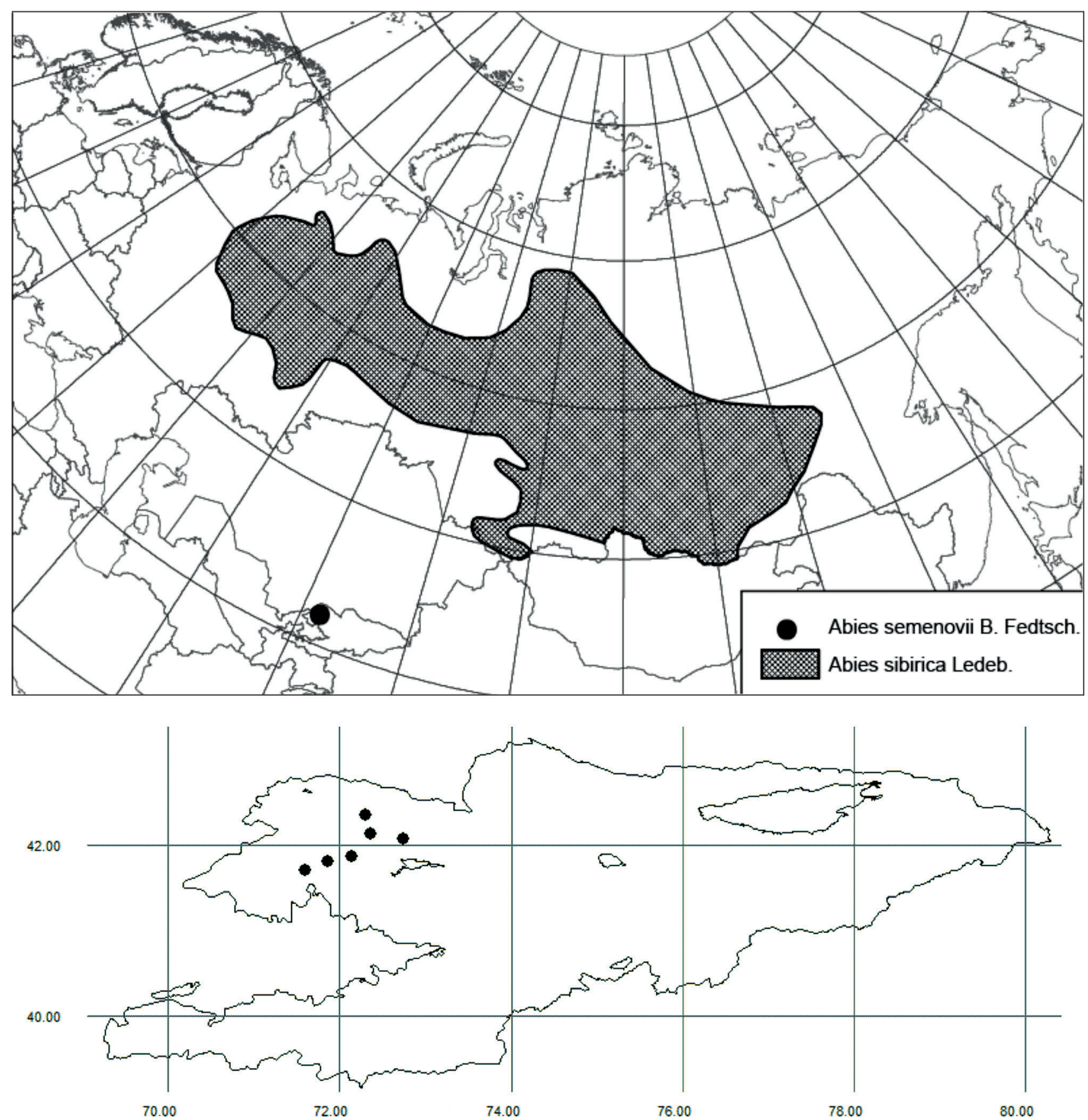

Fig. 1. Distribution of Abies sibirica Ledeb. in Russia and A. semenovii B. Fedtsch. in Kyrgyz republic. Area of A. sibirica drawn up of A. Afonin et al. (2008); A. semenovii drawn up of experts G. Lazkov and L. Orlova

Abies semenovii forests are considered relic remains of mesophyte forests of the Tertiary period. Over the past two centuries, it has been under increasing anthropogenic pressure and it occupies nowadays an area of only about 3470 ha and pure stands are very rare. The main threats are from felling and cattle grazing. Semenov's Fir was included in the International Red Data List of Conifers (Farjon \& Page, 1999), in the Red Data Book of the USSR (Krasnaya kniga SSSR, 1978, 1984) and the Red Data Book of the Kyrgyz Republic (Krasnaya kniga Kyrgyzskoj SSR, 1985; Red Data Book of Kyrgyz Republic, 2006).
Semenov's Fir is closely related to the Siberian Fir, which occupies huge territories in the north eastern part of European Russia, throughout Siberia, Kazakhstan and Mongolia. However, their ranges do not overlap (Fig. 1).

The species was described by Boris Fedtschenko (1898) as an independent species, Abies semenovii B. Fedtsch., based on specimens collected and sent to him by V.A. Kallaur from Bish-Tash Gorge in the mountains of the Talas Alatau, Western Tien Shan (Kyrgyzstan). We should bear in mind that Fedtschenko's original description of a new species 
was only based on a study of the morphological and anatomical structure of vegetative organs, namely, the needles of the fir, i.e. on incomplete material. Apparently, this was one of the reasons for the subsequent conflict and misunderstanding by different authors of its taxonomic status.

The first mass collection of Semenov's Fir was made by Litvinov in 1899 while travelling through Western Tien Shan. As a result of careful study of these herbarium specimens Korzhinsky (1900) concluded that the morphology of $A$. semenovii was almost identical to that of $A$. sibirica. The opinion of Korzhinsky (1900) was supported by a number of botanists, in particular, Petunnikov (1900) and Viguie \& Gaussen (1929), as well as Rehder (1949).

Other experts considered this taxon to have the rank of a variety - A. sibirica var. semenovii (B. Fedtschenko) Farjon (Wu \& Raven, 1999), a subspecies - Abies sibirica Ledeb. subsp. semenovii (B.Fedtsch.) Farjon (Liu, 1971; Farjon \& Rushforth, 1989; Farjon, 1990, 2001; Auders \& Spicer, 2012) or a separate and independent species (Beissner, 1897; Komarov, 1934; Vasiliev \& Ukhanov, 1949; Protopopov, 1952; Matzenko, 1956, 1964; Gaussen, 1964; Bobrov, 1978).

Matzenko $(1956,1964)$, the monographer of the genus Abies, considers that Abies semenovii belongs to the series Sibiricae Matz. of section Piceaster together with Abies pindrow Royle and A. sibirica Ledeb. Siberian Fir, in her opinion, is the youngest species in this section as judged from the fact that the bract scales of mature cones are poorly developed.

According to Kamelin (1973), A. semenovii is a derivative race of firs from the Piceaster section, closely related to A. webbiana (Wall. ex D. Don) Lindl. (= Abies spectabilis (D. Don) Spach).

Bobrov (1978) accepted the opinion of Matzenko (1964) and came to a very important conclusion, that the differentiation of spruce and fir species in these groups proceeded conjugately and at the same time, during the Neogene and Quaternary time, and was originally associated with the manifestation of the Alpine orogeny. Along with the dominant species, some other species were covered by the process of differentiation, which are in fact the subordinate elements of conifer formations. Therefore, according to Bobrov (1978), the formations of these fir and spruce species in the Himalayas, Tian Shan and throughout the taiga zone, should be considered as replacement ones.

It is stated in the "Flora of China" (Wu \& Raven, 1999) that A. sibirica var. semenovii (B. Fedtschenko) Farjon (A. semenovii B. Fedtschenko) is found only in Kyrgyzstan and A. sibirica var. sibirica (A. sibirica Ledeb.) in Chinese territory.

According T.S. Liu (1971), Abies sibirica subsp. sibirica and A. sibirica subsp. semenovii belong to section Pichta.
A. Farjon \& K.D. Rushforth (1989) considers this fir and Abies sibirica subsp. sibirica along with $A$. kawakamii (Hayata) T. Ito, A. balsamea (L.) Mill. and A. lasiocarpa (Hook.) Nutt. as part of the subsection Laterales Patschke of section Balsamea Engelm. In another subsection Medianae Parschke they includes $A$. sachalinensis F. Schmidt, A. fraseri (Pursh) Poir., A. koreana E.H. Wilson, A. nephrolepis (Trautv.) Maxim. and A. veitchi Lindl. According these authors, Himalayan firs belongs to different groups of Abies: A. pindrow - to subsection Holophylla Farjon \& Rushforth (sect. Momi Franco) and A. spectabilis - to subsectiom Delavayanae Farjon \& Rushforth (sect. Pseudopicea Hickel).

Modern researchers (Eremin \& Raskatov, 1974; Semerikova et al., 2012) confirm the rank of this taxon as an independent species. Genetic studies by Semerikova and co-authors (Semerikova et al., 2012) indicate a close relationship and a common origin of A. semenovii and A. sibirica in the past but current research confirms the independence of $A$. semenovii. Semerikova et al. (2012) conducted a study to compare the genetic polymorphism of $A$. semenovii with genetic polymorphism in related fir species $-A$. gracilis, $A$. sibirica and $A$. nephrolepis and inferred the history of $A$. semenovii and the severity of the genetic loss incurred by this isolated marginal species. These authors found that $A$. semenovii was significantly differentiated from the Siberian fir Abies sibirica and deserves to be considered as a species. They did not detect the gene flow between the two species. Moreover, they observed a very low nuclear genetic diversity of $A$. semenovii suggesting a prolonged restricted effective population size. Further molecular studies of these authors (Semerikova et al., 2014) based on cpDNA and mtDNA indicate deep difference between the clade of A. sibirica-A. semenovii and Himalayan firs and confirmed much closer relationship of $A$. sibirica and A. semenovii to Far East firs of sect. Balsamea.

In the information retrieval system "Botanical Collections of Russia and of Neighboring Countries» (http://garden.karelia.ru/) A. semenovii is highlighted for two centers of arboriculture in North west Russia: Peter the Great Botanic Garden of the Komarov Botanical Institute RAS (BIN) and the Polar-Alpine Botanical Garden-Institute, Kola Scientific Center RAS (PABSI). For the rest Russia, it is highlighted for five other arboreta. These are: Botanical Garden-Institute of Mari State Technical University; Botanic Garden of the Nizhny Novgorod State University named N.I. Lobachevsky; Botanical Garden-Institute of Ufa Scientific Center, Russian Academy of Sciences; Main Botanical Garden named N.V. Tsitsin RAS and Sakhalin Botanical Garden FEB RAS.

In connection with the preliminary analysis of data on the taxonomy, distribution and ecology of A. semenovii the following tasks are discussed in this article: 
1. The taxonomic status based on a critical analysis of the literature data and the study of herbarium specimens both from the wild and from different herbaria.

2. The possibilities of Ex situ conservation of A. semenovii in North West Russia.

\section{Material and methods of taxonomic study}

To clarify the taxonomy of species literary sources have been used, including historic and taxonomic information, herbarium collections and the original authors' data. We have studied specimens of Pinaceae kept in Russian (LE, LECB, KFTA, MW, MHA, NS, NSK, TK, KW, VLA) and other herbaria (C, E, H, HBG, KRAM, K, KOR, PE, PR, PRC, BP, W, Z), including types (Orlova \& Christensen, 2002; Orlova, 2002, 2004a,b; Orlova \& Byalt, 2006, 2008; Christensen \& Orlova, 2006), and the Herbarium of the Institute of Biology and Soil of Kyrgyzstan, as well as digital images of type specimens in various herbaria available on the Internet. In addition, during an expedition in Kyrgyzstan in September-October 2015, we studied two populations of Semenov's Fir in the wild. It is located in the Dzhalal-Abad region of Kyrgyzstan, specifically in the Toktogul administrative district of Kyrgyzstan, at Chichkan Gorge on the bank of the Naryn River $\left(42^{\circ} 05^{\prime} 45.8^{\prime \prime} \mathrm{N}, 72^{\circ} 48^{\prime} 26.4^{\prime \prime} \mathrm{E}, 1612 \mathrm{~m}\right.$ a.s.l.) and in Aksy District, on the shore of Sary-Chel-

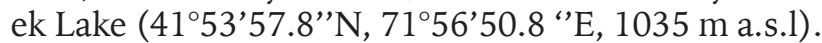

The Red Data books of different levels for this territory were analyzed.

In order to assess the prospects for introduction we have collected the information on the results of tests of cultivation of Semenov's Fir in botanical collections at BIN and PABSI based on our own longterm observations and available literature data. The current state of trees was estimated including their winter hardiness. Biometric measurements of trees and cones were also taken.

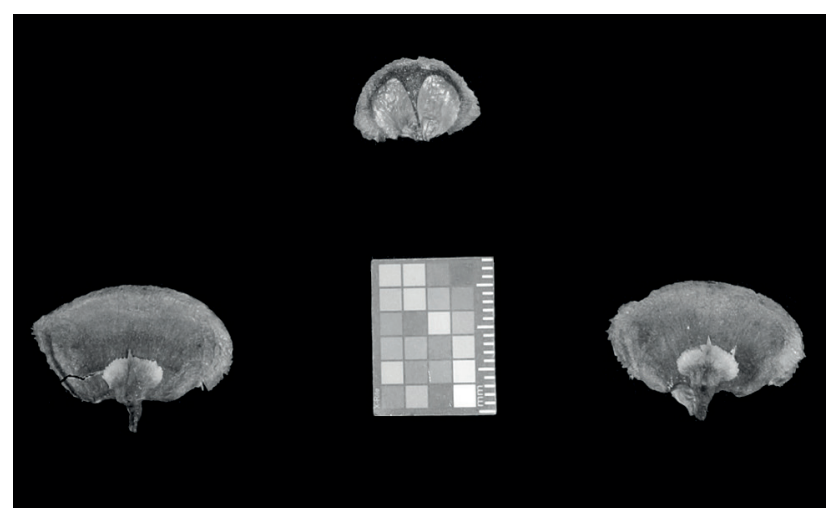

Fig. 2. Seed and bract scales of Abies semenovii B. Fedtsch. Photo 2015: A. Khmarik

\section{Discussion}

\section{Taxonomy of Abies semenovii}

As a result of studies of the literature data devoted to this taxon, it can be concluded that the signs by which A. semenovii may be distinguished from closely related $A$. sibirica, are not sufficiently clear. For example, Komarov (1934) and some other authors suggest the only differences are the longer (up to 4 $\mathrm{cm}$ length) and softer needles in A. semenovii. Vasiliev and Ukhanov (1949) mentioned also the wider seed and bract scales, and the shorter wing of the seed (in A. sibirica the wing of the seed is 2 times longer than the seed itself, while in A. semenovii it is only 1.5 times).

Matzenko $(1956,1964)$ identified differences in the shape of bract scales, the appendage of the microsporophylls and in the morphology of needles and apical buds. Thus, in A. semenovii the width of bract scales is nearly double the length, $4-5 \mathrm{~mm}$ long, 8 $\mathrm{mm}$ wide while in A. sibirica it is rounded and its width is equal to its length, about $5 \mathrm{~mm}$ ) (Fig. 3). The appendage of the microsporophylls in A. semenovii is very small, barely noticeable, while in $A$. sibirica it is well marked and has the shape of an elongated beak. There are also differences in the morphology of needles: in A. semenovii they are 35-38 mm long, 1.8$1.9 \mathrm{~mm}$ wide, with 4-5 stomatal lines on each side of the keel, and in A. sibirica - 20-29 mm long, 1.3-1.7 $\mathrm{mm}$ wide, and with 5-6 stomatal lines. In addition, the apical buds of $A$. semenovii are larger (3.5-4.5 mm long) and not very resinous, while in A. sibirica they are $2-3 \mathrm{~mm}$ long and are strongly resinous.

Therefore, special attention has been paid to the search for stable morphological signs that would help in distinguishing this taxon from other similar species and help to clarify its taxonomic status.

According to our investigations, in addition to those already mentioned, this taxon is well characterized by the presence of a prominent white wax coating on the adaxial side of needles while in A. sibirica

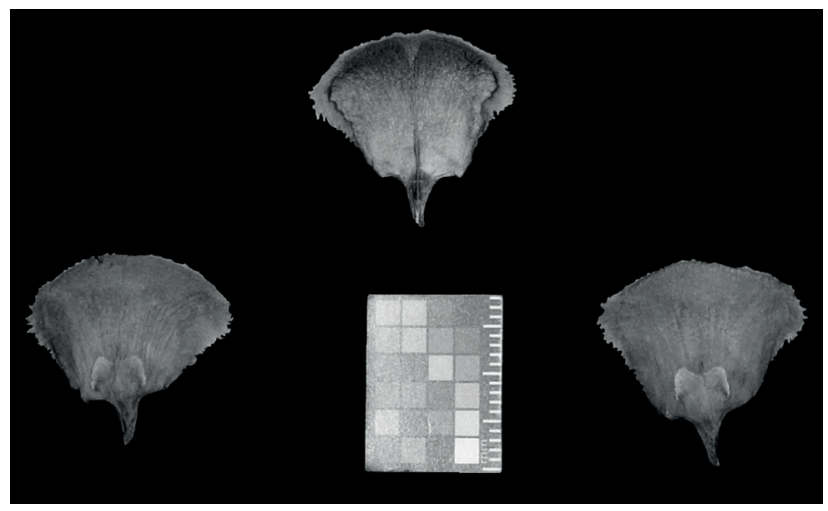

Fig. 3. Seed and bract scales of Abies sibirica Ledeb. Photo 2015: A. Khmarik 


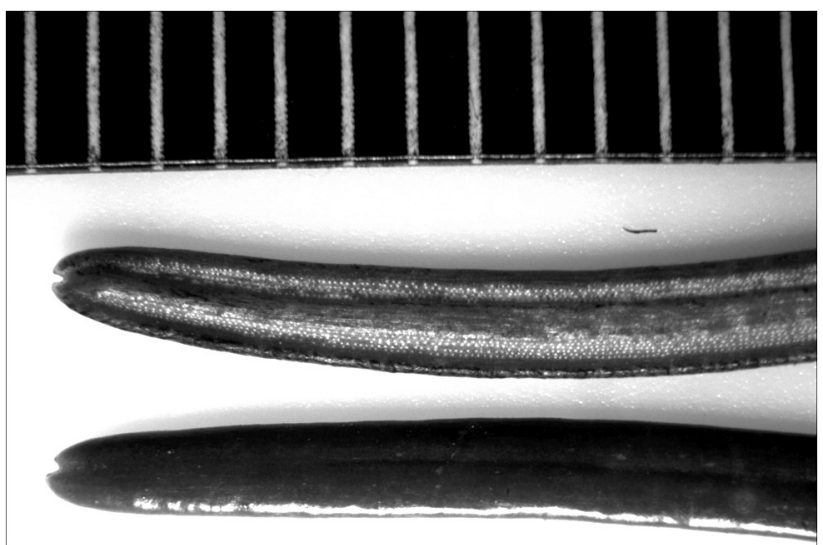

a)

b)

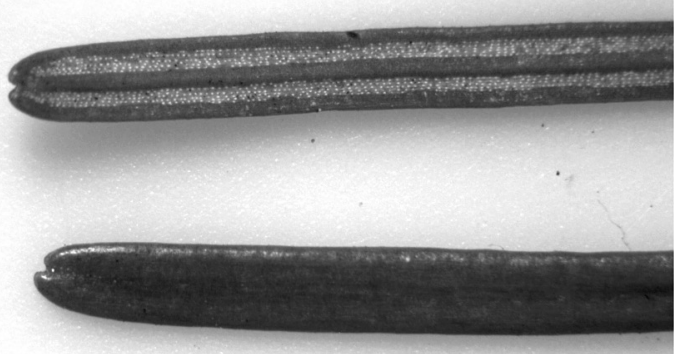

Fig. 4. Needles (upper and under side with keel) of (a) Abies semenovii B. Fedtsch. and (b) A. sibirica Ledeb. Photo 2013: S. Ivanov, A. Khmarik

the white coating is not expressed. There is also the presence of the larger keel, particularly in the central part of the needles, which divides the stomata lines (Fig. 4). In A. sibirica the keel is more or less narrow and of uniform width throughout the whole needle. There is also a more pronounced notch at the top of the needle (the needles are emarginate on vegetative shoots). The shape of the notch is often triangular, with straight edges, or sometimes rounded-triangular (Fig. 4). In A. sibirica the notch at the top of the needle is expressed rather weakly, and it always has rounded edges. In addition, our study confirms those previously identified characters of Semenov's Fir - the longer and wider needles (35-38 mm long, $1.8-1.9 \mathrm{~mm}$ wide compared with $-20-29 \mathrm{~mm}$ and $1.3-1.7 \mathrm{~mm}$ in $A$. sibirica) and longer apical buds $(3.5-4.5 \mathrm{~mm})$ which are not very resinous while in A. sibirica the buds ( $2-3 \mathrm{~mm}$ long) are very resinous.

A comparative study of Abies semenovii and the Himalayan species, Abies pindrow and A. spectabilis, which are united with Semenov's Firs by some authors (Matzenko, 1956, 1964; Kamelin, 1973), revealed some similarities in the structure of vegetative organs. Thus, both the Himalayan species of Abies have a clearly expressed triangular notch at the top of the needles and a bright white wax coating on both sides of the keel on the adaxial side of the nee- dles. These morphological features are also typical for Abies semenovii, but they are expressed to a lesser extent. Unfortunately, we do not have a lot of herbarium material of these rare species, so we cannot here indicate other morphological characteristics that are similar to those of Abies semenovii.

Species of subsection Medianae (Farjon, 1990) characterized by distinct morphological features of the vegetative organs, the notch at the top of the needle is rounded and the wax coating on both sides of the keel on the adaxial side of needles is significant only in A. veitchii and $A$. koreana, in the other species it is not so prominent. In addition, species of this subsection have different shape of seed scales - reniform (in subsection Lateralis - cuneate-flabellate).

Thus, according our study of the morphology of vegetative and reproductive organs, Abies sibirica and A. semenovii are closer Himalayan firs, Abies pindrow and $A$. spectabilis but their relationship with the species of subsection Medianae also is unquestionable.

\section{Semenov's Fir in the Red Data Books and its conservation}

Semenov's Fir was included in the first preliminary edition of native species requiring protection (Krasnaya kniga, 1975) with information that it is a narrow endemic of Central Asia. The species was included in the Red Data Book of the USSR (Krasnaya kniga SSSR, 1978, 1984), the Red Data Book of the Kyrgyz Republic (Krasnaya kniga Kyrgyzskoj SSR, 1985; Red Data Book of Kyrgyz Republic, 2006) and The Red List of Trees of Central Asia (Eastwood et al., 2009) as an independent species A. semenovii B. Fedtsch., and it was also included in the Global Red List of Conifers (Farjon \& Page, 1999) as A. sibirica Ledeb. subsp. semenovii (B. Fedtsch.) Farjon as a vulnerable taxon (VU).

Limiting factors and possible measures of protection are pointed out in the Red Data Book of the Kyrgyz Republic (2006:61): "uncontrolled felling in past, conflagrations, excessive pasturage, viral infections and mycosis (by fir sooty-bark Cenangium abietis (Pers.) Rehm. (Discomycetes). It is necessary to annex areas adjacent to Sary-Chelek Nature Reserve with the most valuable Abies-plantations and to establish forest reservations in Koro-Karagai, Bugu-Ter and Kan-Djailoo localities at Toktogul district."

There are 6 taxa of conifers identified in "Species Summaries" (Pinaceae and Cupressaceae families) of the native flora of Russia and of the former USSR in the World List of Threatened Trees (Oldfield et al., 1998) including Semenov's Fir, as A. sibirica Ledeb. subsp. semenovii (B. Fedtsch.) Farjon. According to the compilers' opinion, the known populations of 
this taxon are restricted to Talassky Ala-Tau in Kyrgyzstan and, supposedly, adjacent districts of China.

It is listed to the Red Data Book of woody plants of Central Asia (Eastwood et al., 2009) with status CR (as critically endangered species), with very limited area of distribution about $100 \mathrm{sq}$. $\mathrm{km}$ at two districts only (Talas and Chatkal). The forest cutting and diseases are pointed as main threats. The global changes of the climate are also more and more dangerous for natural woody vegetation of Central Asia.

Bikirov (2011) has developed a program for the conservation and restoration of Fir forests of Kyrgyzstan until 2025. This is required to diminish anthropogenic pressure, such as extra cattle grazing and illegal felling, and may help to prevent further degradation and decay of fir forests, increase its steadiness and help to promote the enlargement of forest covered territories (Bikirov, 2011).

Scientists of the Institute of Forestry after P.A. Ghan of the National Academy of Sciences of the Kyrgyz Republic took a series of measures to preserve Semenov's Fir (Surappaeva, 2013): a. selected 70 units as plus trees; b. created approximately 1 ha clonal plantation of it; c. allocated 1172 ha forest reserves and d. 155 ha of permanent seed selection sites for it.

\section{Abies semenovii in cultivation}

It is clear that Semenov's Fir is an extremely rare taxon in cultivation, and it is not touched by selection. In "Namensliste der Koniferen" (Erhardt, 2005) the taxon is mentioned only as a synonym for $A$. sibirica. It is absent in the well-known "The Hillier Manual of Trees and Shrubs" (2003). As a new taxon recently involved in cultivation in Western Europe, Semenov's Fir was included in "New Trees" (Grimshaw \& Bayton, 2009) as a subspecies: A. sibirica Ledeb. subsp. semenovii (B. Fedtsch.) Farjon. USDA Hardiness Zone 2: "Seed of subsp. semenovii collected by John Silba in the Tien Shan in 1989 is the only introduction of this taxon that we can trace, but material seems to have been disseminated quite widely. For Keith Rushforth (pers. comm. 2007) in Devon it has proved hardier than subsp. sibirica which has died out for him, subsp. semenovii by contrast having grown, slowly, to almost $2 \mathrm{~m}$ (in 15 years). At Howick, two specimens planted in 1992 are about $2.5 \mathrm{~m}$ tall and have not been damaged by frost though they have been reluctant to form good leaders (C. Howick, pers. comm. 2007). There is also a small tree at Wakehurst Place".

According to Svjazeva (2005), Semenov's Fir appeared in a collection collection of Peter the Great Botanic Garden (Saint-Petersburg, Russia) for the first time in 1949 (seeds from Dzhalalabad and Frunze) but the original sample has not survived. It was reported in the first volume of "Trees and Shrubs of the USSR" (Vasiliev \& Ukhanov, 1949) that up to that moment Semenov's Fir was unknown in cultivation. Apparently, the honour of introducing Semenov's Fir into cultivation at European gardens belongs to Peter the Great Botanic Garden at St. Petersburg. Vasiliev and Ukhanov (1949) considered this fir undoubtedly valuable for tests in horticulture for the area where Saint-Petersburg is situated $\left(60^{\circ} \mathrm{N}\right)$ - they recommended it for Crimea, Caucasus, South West Ukraine and Belorussia.

At Peter the Great Botanic Garden, Semenov's Fir is represented by three trees of the same age and provenance. They form a group of closely planted trees in an open light place but protected from winds. According to Golovach (1980), the seeds of the existing trees were received, apparently, from the wild of Kyrgyzstan and germinated on 4 May, 1958. At that time the species was not cultivated in other botanic gardens. The young plants were replanted from the nursery to the Arboretum on 28 September 1970. According to Golovach's data, the trees measured in 1975-1976 reached the height $1.1 \mathrm{~m}$ only, with an annual growth of 4-9 cm, without frost damage.

Our personal experience and the analysis of literature data has shown that in other botanic gardens of Russia cultivation of Semenov's Firs began later than in St. Petersburg - and consequently, the plants in other arboreta are younger and of smaller sizes. So, in the Main Botanic Garden of Russian Academy of Sciences in Moscow two trees of Semenov's Fir have been cultivated since 1964 . They have reached a height $2.8 \mathrm{~m}$ with trunk diameter $4-7 \mathrm{~cm}$ in the age of 26 years - the trees are of slow growth with annual growth of shoots $3-5 \mathrm{~cm}$, in vegetative state (Plotnikova et al., 2005).

Our field investigation in 2008 and 2009 at the Arboretum of the Polar-Alpine Botanic Garden in Apatity, Murmansk Region, has shown that there are 2 trees of this species in the collection, which were planted in 1986. They are 0.8 and $0.5 \mathrm{~m}$ high. They are multi-stemmed and very badly affected by frost. Apparently, they never will grow above the snow level. According to information from the literature (Kazakov, 1993), these plants were grown from seeds obtained from Frunze (now Beshkek - the capital of Kyrgyzstan). At that time, they were grown in a cold greenhouse and in 4 years had a height of $13 \mathrm{~cm}$. Part of the seedlings disappears annually, although overwinter without visible damage. It is known from phenological observations that the growth of shoots begins at the end of June, and lasts for 10-12 days, with renewed growth in August (Kazakov, 1993).

It is well known that $A$. sibirica, being a cold resistant timber tree of continental climates, does not prosper in the mild climate of Western Europe with unstable temperatures in spring, and it is often 
damaged by late spring frosts (Vasiliev \& Ukhanov, 1949). At Peter the Great Botanic Garden of St. Petersburg Semenov's Fir was never damaged by frosts, even in the coldest winters. Buligin et al. (1989) also pointed out that this fir was never touched by frosts, at that time the trees were in a vegetative state and at 29 years old the fir reached $3.7 \mathrm{~m}$ in height, $4 \mathrm{~cm}$ of trunk diameter and $2.5 \mathrm{~m}$ - projection of crown. At present, the lower branches which touched the ground have rooted and thus it is possible to replant several young plants from the mother tree to the nursery. Semenov's Fir is no less robust than other fir species in the conditions of a large industrial city, at least if planted in the central part of a park far away from roads. The analysis of needle damage made in 2014 by L.N. Scherbakova (St. Petersburg State Forest Technical University) has shown that it is damaged by the spruce-fir Siberian aphid (Aphrastasia pectinatae Chol.) but to a small degree which does not spoil its decorative qualities.

The Semenov's Firs have produced cones since 2000 when they were 43 years old. There was only one tree at first with a few cones but nowadays all three trees produce many cones on the upper part of the crown, which promotes cross-pollination.

Up to the autumn of 2010 these 3 trees reached the following sizes: the height of the tallest tree $15.0 \mathrm{~m}$ high with $26 \mathrm{~cm}$ trunk diameter, The other two trees were of equal height $-13.5 \mathrm{~m}$, with $21 \mathrm{~cm}$ diameter. The projection of the crown, common for the whole group was $8.0 \times 6.5 \mathrm{~m}$. The needles live for up to 10 years. The sizes which $A$. semenovii has reached at Peter the Great Botanic Garden, apparently, are the largest of any at botanic gardens of the globe. Up to the autumn of 2013 the tallest tree had reached $16.0 \mathrm{~m}$ high with $32 \mathrm{~cm}$ of trunk diameter. The sizes of trees continue to enlarge. In autumn 2015, having reached 57 years old, their sizes are as follows: a) $17.4 \mathrm{~m}$ high, $25 \mathrm{~cm}$ in trunk diameter, $4.5 \times 6.0 \mathrm{~m}$ in crown projection; b) $16.0 \mathrm{~m}$ high, 26 $\mathrm{cm}$ diam., $5.7 \times 4.4 \mathrm{~m}$ crown; c) $18.0 \mathrm{~m}$ high, $32 \mathrm{~m}$ diam., $8.0 \times 4.2 \mathrm{~m}$ crown. Measurements of height trees in different years are shown in Table 1.

The cones were observed for the first time in 2010. The cones are light-brown, more or less resinous and they began to ripen in the last ten days of September. The weight of a cone was $9.05 \mathrm{~g}$ on average (from

Table 1. Biometrical measurements of Abies semenovii at Peter the Great Botanic Garden, St. Petersburg, at different age (the best specimen)

$\begin{array}{ccccc}\text { Year } & \text { Age } & \text { Diameter, cm } & \text { Height, } m & \text { Annual growth, cm } \\ 1976 & 18 & - & 1.1 & - \\ 1987 & 29 & 4 & 3.7 & 24 \\ 2010 & 52 & 26 & 15.0 & 49 \\ 2013 & 55 & 32 & 16.0 & 33 \\ 2015 & 57 & 32 & 18.0 & 32\end{array}$

7.43 till $11.30 \mathrm{~g})$, the length was $64(58-70) \mathrm{mm}$, the width at the basal part was $18(16-20) \mathrm{mm}$ and at the widest place $28(26-30) \mathrm{mm}$. There were, on average, 134 (100-153) seeds per cone. The weight of 1000 seeds was $7.9 \mathrm{~g}$. The seeds were spoilt almost completely by certain insects. According to the identification by an entomologist of St. Petersburg State Forest Technical University Dr. B.G. Popovichev, they belong to Dioryctria sp., more probably D. abietella F. As a comparison Vasiliev and Ukhanov (1949) reported the parameters of cones for A. sibiri$c a$ as $5.0-9.5 \mathrm{~cm}$ long, $2-4 \mathrm{~cm}$ wide and the weight of 1000 seeds as $11 \mathrm{~g}$.

\section{Conclusions}

This research confirms the rather clear morphological differences between Abies semenovii and Abies sibirica. Our investigations also confirm that $A$. semenovii differs from the closely related taxon, A. sibirica, by certain characters of the vegetative organs, in particular, the presence of a prominent white wax coating, a larger keel on the adaxial side of the needles and a more pronounced notch at the top of the needle. A. semenovii can be distinguished at the rank of a separate, independent species, closely related but not identical to $A$. sibirica, with which it is included in the series of Sibiricae Matz. According our study of the morphology of vegetative and reproductive organs, Abies sibirica and A. semenovii are closer Himalayan firs, Abies pindrow and A. spectabilis but their relationship with the species of subsection Medianae also is unquestionable.

Semenov's Fir, A. semenovii B. Fedtsch. is an extremely rare taxon in the wild and it is listed in Red Data Books of the former USSR and of Kyrgyz Republic and international Red Data Books as a separate species or a subspecies of the Siberian Fir.

It has been cultivated at Peter the Great Botanic Garden of the Komarov Botanical Institute RAS (St. Petersburg) since 1949. Apparently, it was here that Semenov's Fir was first introduced into cultivation in European gardens. The sizes, which have been achieved are the most prominent known ex-situ. It produces seeds since 2000 , under the age 43 years old. It is valuable as a decorative tree because of its dense dark-green needles and magnificent and luxuriant low crown, with branches down to the ground. It is promising for planting in groups or as single trees in parks and forest parks. Semenov's Fir needs more careful in situ and ex situ conservation.

\section{Acknowledgements}

The authors of this article express their gratitude to Dr. G.A. Lazkov (Institute for Biology et Soil, 
Academy of Science, Kyrgyzstan), officials of the Sary Chelek state reserves for help with sampling and for clarification of the drawing of the area of Abies semenovii. We thank colleagues of St. Petersburg Forest Technical University, Dr. L.N. Sherbakova and Dr. B.G. Popovichev, for their help in needle and seed pests identification, and a student of the same University, P.S. Kirillov, for his help in collecting cones and, also, A. Afonin (St. Petersburg State University) for the map, S. Ivanov and A. Khmarik (St. Petersburg Forest Technical University) for photographs. Special thanks for editing the English language Keith Chamberlain (Rothamsted Research, UK).

The present study was supported by the Ministry of Education and Science of the Russian Federation on the program "Development of Scientific Potential of Higher Education (2009-2011)" project № 2.2.3.1/318 (2.2.3.1/9788), № 2.1.1 / 3859 (2.1.1 / 11545 ) and in 2014 the project number 2014 / 1812220; and R\&BR project № 14-04-01418, and was carried out within the framework of the institutional research project (no. 52.5) of the Komarov Botanical Institute of the Russian Academy of Sciences.

\section{References}

Afonin AN, Greene SL, Dzyubenko NI \& Frolov AN (2008) Interactive Agricultural Ecological Atlas of Russia and Neighboring Countries. Economic Plants and their Diseases, Pests and Weeds. Online http://www.agroatlas.ru.

Auders AG \& Spicer DP (2012) Royal Horticultural Society encyclopedia of conifers: a comprehensive guide to cultivars and species. V. 1. Abies to Picea. Kingsblue Publishing Limited in association with Royal Horticultural Society.

Beissner L (1897) Conifères de Chine. Bullettino della Società botanica Italiana 7: 166-170.

Bikirov SB (2009) Taksonomija pihty Semenova, i ee introdukcija v Kyrgyzstane: Trudy Mezhdunarodnoj nauchnoj konferencii posvjashhennoj stoletiju so dnja rozhdenija P.I. Lapina, chlen-korrespondenta AN SSSR: Problemy sovremennoj dendrologii, Moskva, 30 ijunja - 2 ijulja 2009 (ed. by AS Demidov) KMK Scientific Press Ltd., Moscow, Russia, pp. 545-547.

Bikirov SB (2011) Nauchnye osnovy sokhraneniya i vosstanovleniya pikhtovykh lesov Zapadnogo Tyan'-Shanya. Poligrafbumresursy, Bishkek, Kyrgyzstan.

Bobrov EG (1978) Lesoobrazuyushchie khvoynye SSSR. Nauka, Leningrad, Russia.

Buligin NE, Firsov GA \& Komarova VN (1989) Osnovnye rezul'taty i perspektivy dal'neyshey introduktsii khvoynykh na Severo-Zapade Rossii.
Deponirovano v VINITI, N 3983-V89, Moscow, Russia.

Christensen KI \& Orlova LV (2006) Typification of specific and infraspecific names in Abies, Larix, Picea and Pinus (Pinaceae). Feddes Repertorium 117: 519-525. doi:10.1002/fedr.200611108.

Eastwood A, Lazkov G \& Newton A (2009) The red list of trees of Central Asia. Fauna \& Flora International, Cambridge, UK.

Eremin VM \& Raskatov PB (1974) Anatomical structure of the bark of Abies spp. in Soviet Union (Anatomicheskoe stroenie kory pikht Sovetskogo Soyuza). Botanicheskii zhurnal 59: 680-688.

Erhardt W (2005) Namenliste der Koniferen. Eugen Ulmer KG, Italy.

Farjon A (1990) Pinaceae: drawings and descriptions of the genera: Abies, Cedrus, Pseudolarix, Keteleeria, Nothotsuga, Tsuga, Cathaya, Pseudotsuga, Larix and Picea. Koeltz Scientific Books, Königstein, Germany.

Farjon A (2001) World checklist and bibliography of conifers. Kew, UK.

Farjon A \& Page ChN (1999) Conifers: status survey and conservation action plan. IUCN, Gland, Switzerland and Cambridge, UK.

Farjon A \& Rushforth KD (1989) A classification of Abies Miller (Pinaceae). Notes from the Royal Botanic Garden Edinburgh 46: 59-79.

Fedtschenko B (1898) Abies semenowi mihi, eine neue Tanne aus Centralasien. Botanisches Centralblatt 73: 210-211.

Gaussen H (1964) Les gymnospermes actuelles et fossiles. Genres Pinus (suite), Cedrus et Abies, Fasc. 7. Travaux du Laboratoire Forestier de Toulouse II 1: 273-480.

Golovach AG (1980) Derev'ya, kustarniki i liany Botanicheskogo sada BIN AN SSSR. Nauka, Leningrad, Russia.

Grimshaw J \& Bayton R (2009) New trees: recent introductions to cultivation. The Board of Trustees of the Royal Botanic Gardens, Kew and The International Dendrology Society, UK.

Kamelin RV (1973) Florogeneticheskiy analiz estestvennoy flory gornoy Sredney Azii. Nauka, Leningrad, Russia.

Kazakov LA (1993) Introduktsiya khvoynykh v Subarktiku. Nauka, St. Petersburg, Russia.

Komarov VL (1934) Rod Abies Mill.: Flora SSSR, V. 1 (ed. by VL Komarov \& MM Iljin) Academia Science SSSR, Moskva, Russia, pp. 134-142.

Korzhinsky SI (1900) Zametka ob Abies semenowi Fedcz. Bulletin de l'Académie Impérial e des Sciences de St.-Pétersbourg XII 4: 311-313.

Krasnaya kniga (1975) Dikorastushchie vidy flory SSSR, nuzhdayushchiesya $\mathrm{v}$ okhrane (ed. by AL Takhtadzhyan) Nauka, St. Petersburg, Russia. 
Krasnaya kniga SSSR (1978) Redkie i nakhodyashchiesya pod ugrozoy ischeznoveniya vidy zhivotnykh i rasteniy. Lesnaja promyshlenost', Moskva, Russia.

Krasnaya kniga SSSR, V. 2. 2nd ed. (1984) Lesnaja promyshlenost', Moskva, Russia.

Krasnaya kniga Kyrgyzskoj SSR (1985) Redkie i nahodjashhiesja pod ugrozoj ischeznovenija vidy zhivotnyh i rastenij. Frunze, Kyrgyzstan.

Liu TS (1971) A monograph of the genus Abies. Ph.D thesis. National Taiwan University, Taipei, Taiwan.

Matzenko AE (1956) O vidovoy samostoyatel'nosti tyan'shanskoy pikhty. Botanicheskiy zhurnal 41: 1504-1509.

Matzenko AE (1964) Pikhty Vostochnogo polushariya. Flora i sistematika vysshikh rasteniy 13 , pp. 3-103.

Oldfield S, Lusty C \& MacKinven A (1998) The world list of threatened trees. Cambridge, UK.

Orlova LV (2002) Tipovye obraztsy nekotorykh taksonov roda Pinus (Pinaceae), khranyashchiesya v Gerbarii Botanicheskogo instituta im. V.L. Komarova (LE). Novosti sistematiki vysshikh rasteniy 34, pp. 287-298.

Orlova LV (2004a) Otdel Pinophyta (Gymnospermae): Katalog tipovykh obraztsov sosudistykh rasteniy Vostochnoy Azii, khranyashchikhsya v Gerbarii Botanicheskogo instituta im. V.L. Komarova (LE). V. 1 (Yaponiya i Koreya). Moskva, St. Petersburg, Russia, pp. 15-20.

Orlova LV (2004b) Tipovye obraztsy nekotorykh taksonov roda Abies Mill. (Pinaceae), khranyashchiesya Gerbarii Botanicheskogo instituta im. V.L.Komarova (LE). Novosti sistematiki vysshikh rasteniy 36 , pp. 260-267.

Orlova LV \& Byalt VV (2006) Konspekt semeistva Pinaceae flory Tuvy. Novosti sistematiki vysshikh rasteniy 38 , pp. 7-22.

Orlova LV \& Byalt VV (2008) Tipovye obraztsy nekotorykh taksonov semeystva Pinaceae Spreng. ex Rudolphi, khranyashchiesya v Gerbarii Botanicheskogo instituta im. V.L.Komarova (LE). Novosti sistematiki vysshikh rasteniy 40, pp. 245-284.

Orlova LV \& Christensen KI (2002) Typification of Pinus pallasiana, $P$. salzmannii and $P$. pityusa (Pinaceae). Nordic Journal of Botany 22: 171-175.

Orlova LV \& Firsov GA (2015) Venäjän harvinaisimmat havupuut. Sorbifolia 46: 17-26.
Petunnikov A (1900) Ueber den Wert anatomischer Merkmale zur Unter-scheidung der Abies-Arten. Allgemeine botanische Zeitschrift für Systematik, Floristik, Pflanzengeographie etc. 7/8: 1-3.

Plotnikova LS, Aleksandrova MS, Belyaeva YuE, Nemova EM, Ryabova NV \& Yakushina EI (2005) Drevesnye rasteniya Glavnogo botanicheskogo sada im. N.V. Tsitsina RAN. 60 let introduktsii (ed. by AS Demidov) Nauka, Moskva, Russia.

Protopopov GF (1952) Podotdel - Gymnospermae Golosemennye: Flora Kyrgyzskoy SSR, V. 1. Paporotnikoobraznye, golosemennye i odnodol'nye iz pokrytosemennykh. Frunze, Kyrgyzstan, pp. 49-73.

Red Data Book of Kyrgyz Republic. 2nd ed. (2006) Bishkek, Kyrgyzstan.

Rehder AA (1949) Manual of cultivated trees and shrubs hardy in North America. The Macmillan Company, New York, USA.

Semerikova SA, Lascoux M \& Semerikov VL (2012) Nuclear and cytoplasmic genetic diversity reveals long-term population decline in Abies semenovii, an endemic fir of central Asia. Canadian Journal of Forest Research 42: 2142-2152. doi:10.1139/ cjfr-2012-0158.

Semerikova SA \& Semerikov VL (2014) Mitochondrial DNA variation and reticulate evolution of the genus Abies. Russian Journal of Genetics 50: 366-377.

Surappaeva V (2013) The states of forest genetic resources in the sec region, national report of the Kyrgyz republic. Food and agriculture organization of the United nations, Ankara, Turkey.

Svjazeva OA (2005) Derev’ya, kustarniki i liany parka Botanicheskogo sada Botanicheskogo instituta im. V.L. Komarova (K istorii vvedeniya v kul'turu). Rostok, St. Petersburg, Russia.

The Hillier manual of trees and shrubs (2003) (ed. by J Hillier \& A Coombes). David and Charles, UK.

Wu ZY \& Raven PH (1999) Flora of China (Cycadaceae through Fagaceae), V. 4. Science Press, Beijing, and Missouri Botanical Garden Press, St. Louis, USA. http://www.efloras.org/.

Vasiliev YY \& Ukhanov VV (1949) Rod 1. Abies Hill. - Pikhta: Derev'ya i kustarniki SSSR, V.1. Izd-vo AN SSSR, Moskva, Leningrad, Russia, pp. 53-103. Viguie MT, Viguie T \& Gaussen H (1929) Revision du genre Abies. Travaux du Laboratoire Forestier de Toulouse 2: 1-66. 